\title{
Unexpected formation of aryl-cyanides during the oxidative decomposition of aryl-cyanocuprates. Transfer of a non-transferable group?
}

\author{
Claudia M. P. Kronenburg, Catelijne H. M. Amijs, Peter Wijkens, Johann T. B. H. Jastrzebski and \\ Gerard van Koten* \\ Debye Institute, Department of Metal-Mediated Synthesis, Utrecht University, Padualaan 8, 3584 CH Utrecht, The Netherlands
}

Received 18 October 2001; revised 27 November 2001; accepted 6 December 2001

\begin{abstract}
Oxidative decomposition of cyanocuprates of the type $\mathrm{CuLi}(\mathrm{CN}) \mathrm{Ar}\left(\mathrm{Ar}=\left[\mathrm{C}_{6} \mathrm{H}_{4}\left(\mathrm{CH}_{2} \mathrm{NMe}_{2}\right)-2\right]^{-}\right.$, 1a) or type $\mathrm{CuLi}_{2}(\mathrm{CN}) \mathrm{Ar}_{2}$ (1b) shows the unexpected formation of aryl-cyanides in up to $30 \%$ yield. C) 2002 Elsevier Science Ltd. All rights reserved.
\end{abstract}

A general synthetic strategy for the preparation of biaryls as found in polyketides, terpenes, lignans, coumarins, flavonoids, tannins, peptides and alkaloids involves the coupling of two aryl units, using either metals or organometallic compounds as catalysts. ${ }^{1-8}$ Sterically hindered biaryls like the binaphthyls ${ }^{2}$ or BINAP $^{3}$ are particularly interesting targets because of their numerous applications as chiral ligands in enantioselective catalytic reactions. Preparative routes involving copper are the thermolysis of organocopper compounds, ${ }^{9,10}$ and the oxidative 'decomposition' of organocopper and-cuprate compounds in the presence of a catalytic amount of $\mathrm{CuOTf}^{11}$ or molecular oxygen $^{12-14}$ (see Scheme 1).

The concept of introducing one non-transferable group in organocuprates caused a major breakthrough in the applicability of cuprates in organic synthesis. Of particular importance are the use of monoanionic acetylenic, ${ }^{15}$ arenethiolate $^{16}$ and cyanide ${ }^{14,17}$ moieties as non-transferable groups. In particular, the development of the so called 'higher-order cyanocuprates' with general formula $\mathrm{CuLi}_{2}(\mathrm{CN}) \mathrm{R}_{2}{ }^{18}$ has contributed to the applicability of organocuprates in organic reactions.

The oxidation of heteroleptic cyanocuprates of the type $\left[\mathrm{CuLi}_{2}(\mathrm{CN}) \mathrm{RR}^{\prime}\right]$ is of special importance because the corresponding hetero-biaryls $\mathrm{RR}^{\prime}$ are formed in high yields. A mechanism for their formation has been proposed see Scheme 2. ${ }^{19,20}$

More recently, we $\mathrm{e}^{21}$ and others ${ }^{22-24}$ have shown that such higher-order cyanocuprates should be formulated as $\left[\mathrm{Ar}_{2} \mathrm{Cu}\right]^{-}\left[\mathrm{Li}_{2}(\mathrm{CN})\right]^{+}$both in the solid state and in solution and that a dianionic copper species $\left(\left[\mathrm{Cu}(\mathrm{CN}) \mathrm{Ar}_{2}\right]^{2-}\right)$ cannot be detected in solution. ${ }^{25,26}$

These new insights prompted us to investigate the oxidative decomposition reaction of recently reported $[\mathrm{CuLi}(\mathrm{CN}) \mathrm{Ar}]$ and $\left[\mathrm{CuLi}_{2}(\mathrm{CN}) \mathrm{Ar}_{2}\right] \quad\left(\mathrm{Ar}=\left[\mathrm{C}_{6} \mathrm{H}_{4^{-}}\right.\right.$ $\left.\left(\mathrm{CH}_{2} \mathrm{NMe}_{2}\right)-2\right]^{-}, \mathbf{1 a}$ and $\mathbf{1 b},{ }^{21}$ respectively), with molecular oxygen. ${ }^{27}$

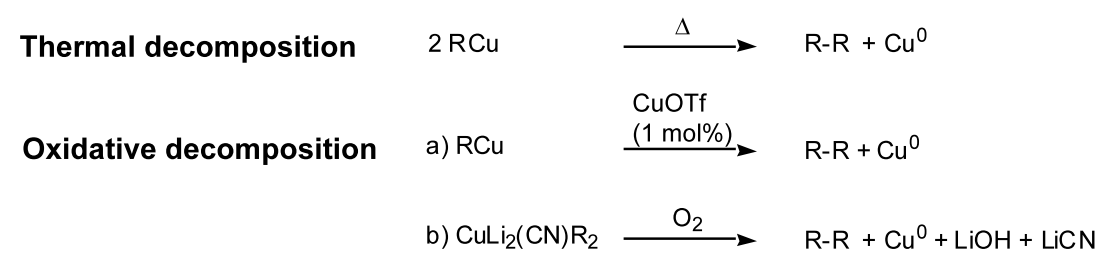

Scheme 1.

Keywords: cyanocuprates; $\mathrm{C}-\mathrm{C}$ and $\mathrm{C}-\mathrm{O}$ coupling; non-transferable groups; oxidation.

* Corresponding author. Tel.: +31 30253 3120; fax: +31 30253 3615; e-mail: g.vankoten@chem.uu.nl 


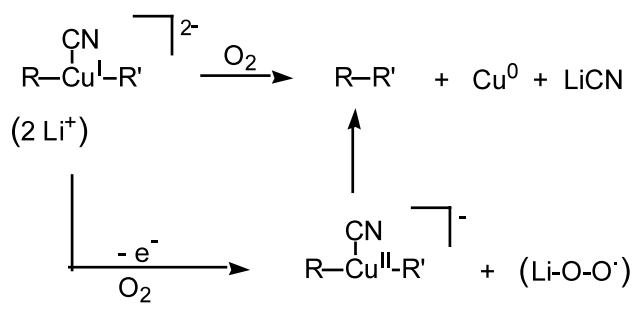

Scheme 2.

The oxidation reactions were performed by bubbling dry air ${ }^{27}$ through THF solutions of $\mathbf{1 a}$ and $\mathbf{1 b}$, respectively, at $-78^{\circ} \mathrm{C}$ for $5 \mathrm{~h}$, after which the reaction mixture was stirred at $\mathrm{rt}$ for $16 \mathrm{~h}$ and subsequently quenched with $\mathrm{D}_{2} \mathrm{O}$ and an aqueous $\mathrm{KCN}$ solution. After work-up the product mixture was analyzed by GC-MS. Under these reaction conditions no deuterium incorporation was observed. This indicated that prior to the work-up procedure all of $\mathbf{1}$ had been converted. However, considerable amounts of $\mathrm{Ar}-\mathrm{D}$ (up to $50 \%$ ) were found when the reaction was quenched after a short reaction time (e.g. $1 \mathrm{~h}$ ), pointing to the presence of unreacted cuprate species. Finally, as all literature procedures reported so far ${ }^{17,28}$ involved the addition of 3 equiv. of TMEDA prior to the reaction, we also carried out reactions both with and without TMEDA. Table 1 shows that in the presence of TMEDA the conversion measured in Ar equivalents is more or less identical to that in the reactions without TMEDA and the actual function of TMEDA in these reactions is therefore not clear.

Four different reaction products could be quantitatively identified in the reaction mixture: (i) the symmetric biaryl, Ar-Ar, (ii) the corresponding phenol $\mathrm{Ar}-\mathrm{OH}$, most likely as a result of insertion of oxygen into an
Ar-metal bond, (iii) minor amounts of $\mathrm{Ar}-\mathrm{H}$, formed by hydrolysis of the cuprate species by traces of moisture in the solvent, and $i v, \mathrm{Ar}-\mathrm{CN}$, as a result of transfer of a cyanide group to the aryl moiety. In particular, the formation of $\mathrm{Ar}-\mathrm{CN}$ was surprising and this is the first observation where a $\mathrm{CN}$ anion behaves as a transferable group. ${ }^{29}$ (Interestingly, the formation of trace amounts of $\mathrm{Ar}-\mathrm{CN}(<1 \%)$ during the oxidation of cyanocuprates has been reported earlier. ${ }^{33}$ ) To demonstrate that the formation of $\mathrm{Ar}-\mathrm{CN}$ in the reported reaction is not a consequence of the presence of the ortho-amino substituent in the aryl ligand, conventional $\mathrm{CuLi}_{2}(\mathrm{CN}) \mathrm{Ph}_{2}$ was oxidized as well. Here, ca. $15 \%$ benzonitrile was found as well as $60 \%$ biphenyl and $20 \%$ phenol.

It is most likely that $\mathrm{Ar}-\mathrm{Ar}$ is formed from species in which two aryl groups are bound to the same metal, e.g. $\left[\mathrm{Ar}_{2} \mathrm{Cu}\right]^{-}$. By analogy, we propose that the formation of $\mathrm{Ar}-\mathrm{CN}$ is most probably the result of the oxidation of a species in which both an Ar-group and a $\mathrm{CN}$-group are bound to the same metal, e.g. $[\mathrm{ArCuCN}]^{-}$. The 2:1 aggregate ('higher-order') cuprate $\mathbf{1 b}$ indeed contains $\left[\mathrm{Ar}_{2} \mathrm{Cu}\right]^{-}$and $\left[\mathrm{Li}_{2}(\mathrm{CN})\right]^{+}$ionic units both in the solid state and in solution. ${ }^{21}$ Recently, the $[\mathrm{ArCuCN}]^{-}$motif has been found in the structure of the 1:1 (lower-order) cuprate $[\mathrm{CuLi}(\mathrm{CN})(t-\mathrm{Bu})] .{ }^{23}$ Based on the results of the oxidation reactions in Table 1 and the structures of the above mentioned species we propose a mechanism as outlined in Scheme 3.

We believe that in solution an equilibrium exists between the 1:1 cuprate $1 \mathbf{a}$ and the 2:1 cuprate $\mathbf{1 b}$. With the present information, it is impossible to predict the position of these equilibria. This makes it difficult to formulate conclusions about the reactivity of the copper-containing ionic fragments since kinetics will play a dominant role in these reactions.

Table 1. Oxidative decomposition reactions of $\mathbf{1 a}$ and $\mathbf{1 b}$ with molecular oxygen at $-78^{\circ} \mathrm{C}^{\mathrm{a}}$

\begin{tabular}{|c|c|c|c|c|c|c|c|}
\hline \multirow[t]{2}{*}{ Entry } & \multirow[t]{2}{*}{ Complex } & \multirow[t]{2}{*}{ TMEDA (equiv.) $^{\mathrm{b}}$} & \multicolumn{3}{|c|}{ Yield of aryl-containing products $\left(\mathrm{mol}^{\mathrm{o}} \mathrm{c}\right)^{\mathrm{c}}$} & \multirow{2}{*}{$\begin{array}{l}\text { Total }\left(\mathrm{mol}^{\%} \%\right) \mathrm{Ar}^{\mathrm{d}} \\
\mathrm{Ar}-\mathrm{CN}\end{array}$} & \\
\hline & & & $\mathrm{Ar}-\mathrm{Ar}$ & $\mathrm{Ar}-\mathrm{H}$ & $\mathrm{Ar}-\mathrm{OH}$ & & \\
\hline 2 & $\mathrm{CuLi}(\mathrm{CN}) \mathrm{Ar}(\mathbf{1 a})$ & 3 & 41 & 5 & 23 & 31 & 72 \\
\hline 3 & $\mathrm{CuLi}_{2}(\mathrm{CN}) \mathrm{Ar}_{2}(\mathbf{1 b})$ & - & 39 & 2 & 32 & 27 & 86 \\
\hline 4 & $\mathrm{CuLi}_{2}(\mathrm{CN}) \mathrm{Ar}_{2}(\mathbf{1 b})$ & 3 & 41 & 5 & 29 & 26 & 71 \\
\hline
\end{tabular}

${ }^{a}$ Reaction conditions: $45 \mathrm{~mL}$ THF; $2.5-5.0 \mathrm{mmol}[\mathrm{Cu}] ;-78^{\circ} \mathrm{C}\left(\mathrm{O}_{2}, 5 \mathrm{~h}\right) \rightarrow \mathrm{rt}(16 \mathrm{~h})$.

${ }^{\mathrm{b}}$ Ratio TMEDA: $\mathrm{Ar}=3: 1$ in molar equivalents.

${ }^{c}$ Determined by GCMS analysis with tert-butylbenzene as internal standard.

${ }^{\mathrm{d}}$ Total amount of Ar equivalents in mol\% recovered after work-up.

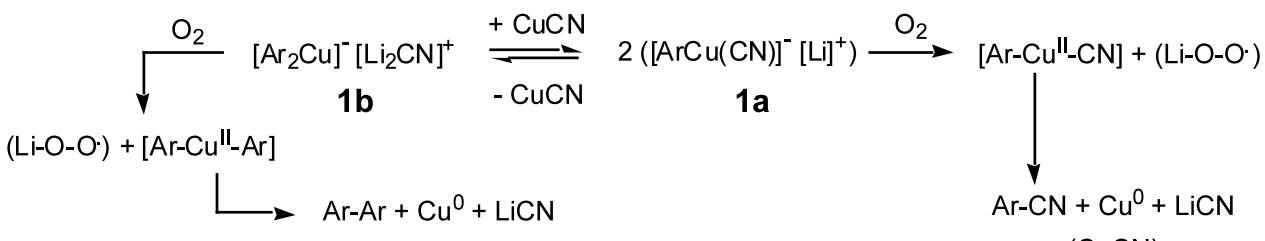

(CuCN)

( $\mathrm{CuCN})$

Scheme 3. 
In principle, oxidation of a solution of pure $\mathbf{1 b}$ would result in the exclusive formation of Ar-Ar. However, during oxidation of $\mathbf{1 b} \mathrm{CuCN}$ is gradually re-formed which shifts the right-hand $\mathbf{1 a} / \mathbf{1 b}$ equilibrium to the side of the 1:1 cuprate $[\mathrm{ArCu}(\mathrm{CN})]^{-}[\mathrm{Li}]^{+} \mathbf{1 a}$. This could explain the formation of $\mathrm{Ar}-\mathrm{CN}$ during this reaction, cf. entries 3 and 4 in Table 1 .

In all reactions $\mathrm{Ar}-\mathrm{OH}$ is formed in comparable yields to $\mathrm{Ar}-\mathrm{Ar}$ and $\mathrm{Ar}-\mathrm{CN}$. This implies insertion of $\mathrm{O}_{2}$ into the $\mathrm{Ar}-\mathrm{M}(\mathrm{M}=\mathrm{Cu}$ or $\mathrm{Li})$ bond of one of the species present in Scheme 3. The formation of excess $\mathrm{Ar}-\mathrm{Li}^{31}$ via the left-hand $\mathbf{1 b} / \mathbf{1 a}$ equilibrium may well be involved. Indeed, this equilibrium will shift to the left because $[\mathrm{ArCu}(\mathrm{CN})]^{-}[\mathrm{Li}]^{+}, \mathbf{1 a}$, is used in the competitive reaction to form $\mathrm{Ar}-\mathrm{CN}$. Oxidative decomposition of ArLi under the same experimental conditions yields $\mathrm{Ar}-\mathrm{OH}$ in $85 \%$.

Recent NMR studies ${ }^{32}$ showed that, apart from equilibria between different copper species, equilibria between contact ion-pairs (CIPs) and solvent-separated ion-pairs (SSIPs) play a dominant role depending on the polarity of the solvents. In solvents like diethyl ether and THF (used for the present reactions) cyanocuprates are predominantely present in the form of SSIP's. This underlines the view that the products $\mathrm{Ar}-\mathrm{Ar}$ and $\mathrm{Ar}-\mathrm{CN}$ originate from 1b and 1a, respectively.

The present work demonstrates that oxidative decomposition of arylcyanocuprates results in the formation of considerable amounts of $\mathrm{Ar}-\mathrm{CN}$ and that a group so far regarded as non-transferable may well be transferred under certain conditions.

\section{Acknowledgements}

Financial support by the Utrecht University is greatly acknowledged.

\section{References}

1. For a review, see: Bringmann, G.; Walter, R.; Weirich, R. Angew. Chem., Int. Ed. Engl. 1990, 29, 977.

2. Noyori, R.; Tomino, I.; Tamimoto, Y. J. Am. Chem. Soc. 1979, 101, 3129.

3. Inoye, S.; Takaya, H. P.; Tani, K.; Otsuka, S.; Sato, T.; Noyori, R. J. Am. Chem. Soc. 1990, 112, 4897.

4. Fanta, P. E. Synthesis 1974, 9.

5. Semmelhack, M. F.; Helquist, P.; Lones, L. D.; Mendelson, L.; Speltz Ryono, L.; Gorzynski Smith, J.; Stauffer, R. D. J. Am. Chem. Soc. 1981, 103, 6460.
6. Armstrong, D. R.; Breckenridge, R. J.; Cameron, C.; Nonhebel, D. C.; Pauson, P. L.; Perkins, P. G. Tetrahedron Lett. 1983, 24, 1071.

7. Echavarren, A. M.; Stille, J. K. J. Am. Chem. Soc. 1987, 109, 5478.

8. Suzuki, A. Pure Appl. Chem. 1991, 63, 419.

9. Janssen, M. D.; Corsten, M. A.; Spek, A. L.; Grove, D. M.; van Koten, G. Organometallics 1996, 15, 2810.

10. van Koten, G.; ten Hoedt, R. W. M.; Noltes, J. G. J. Org. Chem. 1977, 2705.

11. van Koten, G.; Jastrzebski, J. T. B. H.; Noltes, J. G. J. Org. Chem. 1977, 42, 2047.

12. Camus, A.; Marsich, N. J. Organomet. Chem. 1972, 46, 385.

13. Posner, G. H. Org. React. (NY) 1975, 22, 253.

14. Lipshutz, B. H.; Sengupta, S. Org. React. (NY) 1992, 41, 135-631.

15. House, H. O.; Fisher, W. F., Jr. J. Org. Chem. 1969, 34, 3615 and 3627.

16. Van Klaveren, M.; Lambert, F.; Eijkelkamp, D. J. F. M.; Grove, D. M.; van Koten, G. Tetrahedron Lett. 1994, 35, 6135.

17. Lipshutz, B. H.; James, B. J. Org. Chem. 1994, 59, 7585.

18. Lipshutz, B. H.; Wilhelm, R. S.; Koslowski, J. A. Tetrahedron 1984, 40, 5005.

19. Lipshutz, B. H.; Siegeman, K.; Garcia, E. J. Am. Chem. Soc. 1991, 113, 8161.

20. Lipshutz, B. H.; Kayser, F.; Liu, Z.-P. Angew. Chem., Int. Ed. Engl. 1994, 33, 1842.

21. Kronenburg, C. M. P.; Jastrzebski, J. T. B. H.; Spek, A. L.; van Koten, G. J. Am. Chem. Soc. 1998, 120, 9688.

22. Bertz, S. H. J. Am. Chem. Soc. 1991, 113, 5470.

23. Boche, G.; Bosold, F.; Marsch, M.; Harms, K. Angew. Chem., Int. Ed. Engl. 1998, 110, 1779.

24. Hwang, C.-S.; Power, P. P. J. Am. Chem. Soc. 1998, 120, 6409.

25. Gschwind, R. M.; Xie, X.; Rajamohanan, P. R.; Auel, C.; Boche, G. J. Am. Chem. Soc. 2001, 123, 7299.

26. It must be noted that accidentally a salt containing a $\left[\mathrm{Cu}(\mathrm{CN})_{3}\right]^{2-}$ dianion was isolated during crystalisation of a cyanocuprate of type $\mathrm{CuLi}_{2}(\mathrm{CN}) \mathrm{Ar}_{2}$ and its structure in the solid state was solved by X-ray diffraction techniques.

27. Air was dried by passing it consecutively through a cold trap $\left(\mathrm{CO}_{2} /\right.$ acetone), concentrated $\mathrm{H}_{2} \mathrm{SO}_{4}$ and $\mathrm{P}_{2} \mathrm{O}_{5}$ before bubbling through the reaction mixture.

28. Bertz, S. H. J. Am. Chem. Soc. 1990, 112, 4031.

29. The analysis of the Ar- $\mathrm{CN}$ formed in experiments 1 and 3 (Table 1) was identical to that of independently prepared $\mathrm{Ar}-\mathrm{CN}{ }^{30}$

30. Christophel, W. S.; Miller, L. L. J. Org. Chem. 1986, 51, 4169.

31. ArLi is present in $\mathrm{THF}$ as a dimeric species.

32. Gschwind, R. M.; Rajamahan, P. R.; John, M.; Boche, G. Organometallics 2000, 19, 2868.

33. Bertz, S. H.; Gibson, C. P. J. Am. Chem. Soc. 1986, 108, 8286. 